\title{
Performing the National? Scottish cinema in the time of indyref
}

\begin{abstract}
:
This article looks at Scottish cinema during the period 2012-2017, assessing the ways in which the nation's constitutional debate, Scottish-English relations and discourses of national identity were engaged with thematically by films produced in this period. It argues that Scottish cinema in this period 'performs the national', in that a number of films flag their national status and engage with discourses of national identity at a distance, unburdened by any serious demand for national representativeness, as might be the case with a 'national cinema'. From a corpus of texts in the period which offer the possibility of being read through discourses of the nation, two genre films, White Settlers and Sunshine on Leith, are analysed in detail for their differing narrative takes on Scottish-English relations in the contemporary moment. The article concludes by surmising that while film criticism in Scottish cinema has historically been overly-determined by an ideologically driven pursuit of national representativeness, perhaps the welcome emphasis which has been placed in contemporary criticism on broadening the scope of Scottish cinema studies beyond the national has implied a false dichotomy between the two, where it is more likely we can locate Scottish cinema somewhere in between.
\end{abstract}

Keywords: National cinema, indyref, Scottish cinema, transnational, Scottish independence, Brexit, Creative Scotland, Irvine Welsh, The Proclaimers 


\section{Introduction}

Upon the release of Macbeth (2015), The Daily Telegraph's film critic Robbie Collin (2015) praised the film on Twitter, announcing: 'It's a massively significant piece of post-referendum British cinema'. Macbeth, the 'Scottish' play of England's most famous playwright, was adapted by two Americans and an Englishman; directed by an Australian who cast IrishGerman and French actors in the leading roles, and was filmed mostly on Skye, on the northwest coast of Scotland. The film was financially supported by production companies, investment funds and public arts agencies from Australia, Britain, France, Luxembourg, Scotland and the United States. Furthermore, this frequently adapted play has previously been transported to Australia, Brazil, India, Japan and the United States. It has been directed by venerated auteurs of the cinema such as Orson Welles, Roman Polanski and Akira Kurosawa. When Collin locates the film within the socio-political discourses of twenty-first century Britain, he is taken by the relevance of this tale of bloodlust, hubris and madness, of a Scottish civil war ended by the march of an advancing, allied, English army. Collin's implied referencing of the Scottish independence referendum of 2014 indicates how cinema is often still interpreted through its relevance to contemporary events and the persistence of the idea of nation despite the film's inherent transnationalism.

This article investigates Scottish cinema during the period 2012 to 2017, a discursive era marked by the discussion of national identity and constitutional politics in the public sphere. There are two reasons for focusing the scope of this article to this period. Firstly, it offers a look at films released after the notable burst in academic inquiry into Scottish cinema begun by Petrie (2000) and most recently evidenced by publications from Nowland and Finch (2014), Meir (2015) and Murray (2015). Secondly, this article investigates the links between filmmaking in Scotland and the wider socio-political contexts of this era, which has been marked by the agreement between the Scottish and UK governments for a referendum on 
independence in October 2012, the vote itself in 2014, and the Brexit referendum in 2016 which saw Britain vote to leave the European Union. Furthermore, a number of critically and commercially successful Scottish films were released during this time, many of which indirectly reflect the aforementioned political debates around independence for Scotland from the United Kingdom, though the debate does not feature directly in any. I wish to first set a contextual background for the discussion of Scottish cinema that follows, and specifically the analyses of the films White Settlers (2014) and Sunshine on Leith (2013).

I begin with briefly outlining some of the ways in which debates around Scottish national identities and constitutional politics are often approached through cultural specificity. I then outline a corpus of films in this period which can be read as engaging with national and local specificities, including Under the Skin (2013), Filth (2013), Sunset Song (2015), the aforementioned Macbeth (2015) and, to a notably lesser extent, T2: Trainspotting (2017). My thinking on this question has been shaped by long-standing debates about the methodological justification for approaching film culture through a national framework. Elsaesser's (2015) notion that European cinema can no longer represent or construct national identities in the way its post-war variants did in the twentieth century is utilised to try and make sense of Scottish cinema in the contemporary period. Elsaesser argues that contemporary European cinema can be primarily thought of as providing a '...gesture that is both performatively national and postnational' (2015: 28). Finally, I discuss two films which feature cross-border relations, in that both feature English characters choosing to reside in Scotland. Both indicate the variety of film production in Scotland in this period: Sunshine on Leith was a box office success, and was warmly if not wholly enthusiastically received by critics; White Settlers, on the other hand, was a micro-budget feature, which did not receive a wide release and has found little favour with audiences or critics beyond horror film festivals. 


\section{Indyref, political imaginaries and Scottish culture}

Over the last decade in Scotland, constitutional politics and debates around national identity have been intertwined as the nation moved through a referendum on independence from Britain (indyref), and then a referendum on Britain leaving the European Union. Scots voted to remain in both unions, yet the UK-wide decision to leave the EU makes a repeat of the independence referendum (indyref2) a distinct possibility. At the time of writing, Scotland's First Minister Nicola Sturgeon has called, unsuccessfully so far, for Scotland to have the right to vote again on the question of independence in 2020 . To contextualise this moment, this section briefly outlines how the relationships between culture, politics and national identity in Scotland have been theorised. Hames (2020) provides a thorough and persuasive account of the concept of 'cultural devolution' in Scotland from the mid-1960s to the present day. Focusing on literature, Hames (2020) critiques the self-sustaining legitimacy of this argument: that Scotland's writers, and its cultural sphere more broadly, are inextricably linked (and should be inextricably linked) to a process of national self-discovery in Scotland which becomes readable through the continued development of a distinctly Scottish (and increasingly independent) political authority. Cultural devolution has worked in tandem with a period of national movement in Scotland which has seen increasingly divergent voting patterns in Scotland compared to England. The Conservative party's dismantling of the welfare state has, as McCrone notes, been central to this divergence: 'In a country which had turned against the Conservatives as early as the mid-1950s, the attack on the state seemed as much an attack on Scotland itself' (2001: 27).

Central to Hames' (2020) narrative of cultural devolution and literary politics in twentieth-century Scotland was the 'failed' devolution referendum of 1979. In March of that year, Scotland voted on proposals for a Scottish Assembly, which proposed greater devolution of powers from Westminster. 52\% of Scottish voters were in favour of the Assembly, yet as 
the turnout was $64 \%$ this only equated to $33 \%$ of those eligible to vote, thus falling short of the 40\% stipulated by the Scotland Act of 1978 (Devine 2012a). Scotland finally voted for a devolved Parliament in 1997 , with $75 \%$ of voters in favour of the prospect and every local authority returning a Yes vote. The 1979 devolution referendum has been seen as a failure of nerve by the Scottish public, with writer William McIlvanney's allegorical 'Cowardly Lion' poem, written in the aftermath of the vote the most notable critique in this regard. McIlvanney lamented the lion's desire to feed comfortably from a bowl in its cage rather than risk the pursuit of a meal in the freedom beyond its door, as famously illustrated by Jim Turnbull (McCrone 2017: 23). The critical consensus emerging from this period was that while Scotland had failed to achieve political devolution, its writers and artists were fostering a cultural devolution from Britain in the originality, vibrancy and cultural specificity of their work, which found new ways of reimagining debates about national identity and self-determination (Petrie 2004). This is noted by Whyte, who writes: 'In the absence of an elected political authority, the task of representing the nation has been repeatedly devolved to its writers' (1998: 284). This line of argument asserts that the Scottish Parliament's arrival in 1999 was partly made possible by Scotland's artists, and is similarly made by Craig (2014) who writes that 'It was this tide of cultural regeneration rather than political urgency that gave impetus to Scottish devolution in the 1980s and 1990s'.

It may seem a stretch to argue that this cultural devolution of Scotland from Britain in the 1980 s and 1990s is somewhat responsible for the political processes which resulted in the second devolution referendum of 1997, and indeed Hames argues that efforts in 'reconstructing a national political space were symbiotic with efforts to re-conjure national literary space' (2020: 11). McCrone (2009), also counters this version of events, locating the rise in self-determination more in the discovery of oil in the North Sea and Thatcherism, than cultural renewal. Pitten-Hedon (2015) argues that literature in contemporary Scotland has 
begun to move beyond the project outlined by Hames, towards a post-national approach where the focus is less on articulating the specificity of Scotland, but on locating Scotland within global, transnational frameworks. This returns me to Elsaesser's (2015) refrain on European cinema's status as both performatively national and post-national, which I subsequently attempt to untangle with regards to Scottish cinema.

\section{Scottish cinema in the time of indyref}

While the burden of national representativeness has frequently fallen to the literary, filmmaking in Scotland has historically been theorised through national identity frameworks too. Scotland's unique historical status as nation semi-state has had a determining impact upon its cinema, both through the industrial structures necessary for film production frequently being unavailable in Scotland ${ }^{1}$, and the impact that this has had on that cinemas representative norms. While films about Scotland have a long history in the cinema, early critical inquiry into Scottish cinema argued that their impact was negative: the Hollywood and British film industries relying upon a familiar set of tropes in their depiction of Scotland (McArthur 1982). There is not scope to discuss this representative history in detail here, and thorough examinations of the literature can be found in Petrie (2000), Martin-Jones (2009a) and Murray (2015; 2019). However, in discussing Scottish cinema in the time of indyref I build upon the aforementioned authors' arguments that there emerged a 'devolved' or 'new' Scottish cinema from the late 1990s onwards, which featured a variety of confident, self-aware and imaginative films, frequently transnational in both their production contexts and thematic concerns. Films like Trainspotting (1996), Orphans (1998), Ratcatcher (1999), Morvern Callar (2002), Red Road (2006) and the Scottish films by Ken Loach, Paul Laverty and Rebecca O'Brien, to name but a well-known few, have contributed to the understanding of Scottish cinema in this period as increasingly outward-looking and reimagining the historic representative tendencies of old: the trio routinely labelled as Tartanry, Kailyard and Clydesideism. Indeed, Murray argues '...the idea 
of a deliberate, dominant and didactic focus on the question of nation...' was no longer relevant to the range of films produced in the New Scottish Cinema (2012: 400).

The terrain here, as with much contemporary discussion of national cinema, is fraught with difficulties in defining what constitutes a 'national' cinema in an era of screen convergence and the necessity of transnational filmmaking partnerships. But it is also fraught with the desire to avoid the perceived pitfalls of a regressive, constructionist idea of cinema as a progenitor of national identities, an approach exemplified by Higson's argument that 'To identify a national cinema is first of all to specify a coherence and a unity; it is to proclaim a unique identity and a stable set of meanings' (2000: 37). Similarly, Bergfelder writes: 'Indeed, most studies of national cinemas in Europe... remain couched in a rhetoric of cultural protectionism and fear of globalisation, and they still perpetuate in many cases, whether unwittingly or not the illusion of 'pure' and stable national cultures' (2005: 321). However, I adopt the approach of Hjort and Petrie (2007) who argue that examining how cinema may be intertwined with national phenomena need not necessarily result in narrow parochialism. I would contest the depiction of academic enquiry into national cinema as one which historically seeks 'stable meanings' and 'unique identities'. Rather, I take the approach of Brown (2011) whose discussion of transnational Scottish cinema calls for an awareness of the ways in which Scottish cinema can be thought of as both relevant to the place in which it is set, and part of global flows of capital and networks of film production, distribution and exhibition. Indeed, Lim argues that to remain relevant, there needs to be a careful development of '... transnational cinema as a conceptual framework that can be both inescapably national and inadvertently nation-less' (2019: 2).

In the case of Scottish cinema in the period 2012-2017 we can bear witness to the fragmented, illusory and contested nature of national representativeness through a diverse body of films. Under the Skin depicts an alien in the form of a human female with an English accent 
stalking working-class men in Glasgow. I argue elsewhere (Munro 2020) that the film reinscribes Scottish national iconography in its depiction of its urban (Glasgow) and rural (Highlands) landscapes, playing with the cinematic heritage of these spaces and how gender is frequently represented in them. While the film is often seen as an example of Scotland being represented as 'nowhere in particular' (Marmysz 2014), I read the film in line with Massimi (2019: 148) who argues that the film offers a 'gendered remapping of Scotland's current geopolitical landscape'. Filth takes more deliberate aim at Scottish iconography, in the depiction of its lead character Bruce Robertson, a wordplay on Robert the Bruce, the subject of two recent films (Outlaw King (2018) and Robert the Bruce (2019) $)^{2}$. As previously detailed (Munro 2014), the film also highlights this trans/national tension in that while it was awarded more public money from Sweden than Scotland or the UK, the film frequently lampoons Scottish national identity. This is most notable in its opening sequence in which Bruce travels through an Edinburgh-as-heritage space beginning with the city's Castle, past kilted bagpipers and local undesirables, clearly setting up a comedic juxtaposition between the tourist board perspective of Edinburgh (Scotland) versus a caricatured vision of an unhealthy reality ${ }^{3}$. In this sense Filth is a good example of the performativity of nation in contemporary cinema. The parodic engagements with stereotypes of Scotland offer both a knowing wink to local audiences and key points of access for international viewers. But Filth makes no real claims towards national representativeness: there is no thematic weight to the comedic use of Scottish signifiers, and the film is dislocated from an interest in temporal (or historic) socio-political specificity unlike its literary predecessor Porno (Welsh 1998) which often offers a pointed critique at Thatcherite Britain; indeed Bruce's tapeworm is referred to as Arthur Scargill: 'the enemy within'.

Released a year later, Sunset Song offered audiences a long-awaited adaptation of Scotland's most popular novel (BBC 2016). The importance of this national text to the 
bourgeoise-political class, invoking Gellner's (2006) discussion of the function of nationalism, can be seen by its centrality to a debate about culture at the Scottish Parliament, concluded by Culture Secretary Fiona Hyslop with the remarks: 'I look forward to seeing the new "Sunset Song”. It is part of that new song of Scotland and of a Scottish film movement that is not at sunset but rather is heading towards a noontime zenith' (Scottish Parliament 2012). Here the linking of film culture to national identity is overt, but the film too offers multiple reflections on national identities. It adapts nearly verbatim Chris Guthrie's famous interior monologue from Gibbon's novel on the:

'two Chrisses there were that fought for her heart and tormented her... you wanted the words they'd known and used, forgotten in the far-off youngness of their lives, Scots words to tell to your heart how they wrung it and held it, the toil of their days and unendingly their fight. And the next minute that passed from you, you were English, back to the English words so sharp and clean and true-for a while, for a while till they slid so smooth from your throat you knew they could never say anything that was worth the saying at all. (1932: 32$)$

Director Terence Davies underscores this theme in visual terms by cutting from Chris in peaceful repose in a field of barley underneath bright blue skies to Chris in a stuffy, dour school room when the monologue begins. This pictorially represents Smith's (1919) Caledonian Antisyzgy: the Scottish heart belonging to nature and intuition; the English head belonging to an interior world of literate rationality. Similarly, the film ends with a cross-fading montage which represents Bhabha's (1990: 1) 'cultural temporality of the nation'. These shots begin when Chris's darkened home is mysteriously and suddenly filled with light, accompanied by the voice of her dead husband telling her that he has 'come home'. The home, which was for so much of the film represented as a restriction, shot in darkness with Chris often framed by and through windows and doorways, is now a place of warm sanctuary. The sound of bagpipes 
begins as the shot cross-fades to the next, that of the standing stones which repeatedly signify the ending of chapters in the book. Chris's voiceover provides the final lines from the novel, as the shot cross-fades again to that of Chris, alone in the landscape. She mourns those who have died, as the shot cross-fades to provide the viewer with gloomy mountains, a familiar representation of Scotland's rural landscapes. The light of the sun breaks through the clouds and the shot cross-fades again, back to Chris alone in the landscape. Tears fill her eyes, a smile breaks onto her face and the shot once more cross-fades to the silhouette of a piper on the hilltop, before cross-fading to black. This final sequence can also be read as a kind-of national performance. Scotland is a more distant concept in the film than it is the novel, but the film's ending makes us of national iconography and, like Under the Skin, a gendered reading of nation in how these images overlap and dissipate, seeming both part of a whole, yet impermanent and fleeting at the same time.

Finally, T2: Trainspotting is the most successful Scottish film in this time period, making $£ 17$ million at the UK box office and \$44 million globally (BFI 2017). In his review, Peter Bradshaw (2017) remarks 'My only regrets are that T2 failed to get to grips with the new era of \#indyref and Scottish national identity - for which Renton's famous "shite" speech helped plant a tiny seed in 1996'. It is a film which fetishises nostalgia for the good old days, and Murray notes (2017) that the recurring theme of the film, best seen in the case of Spud's misunderstanding of British Summer Time, is the relentless march of time and the consequences of failing to adapt to progress. Murray, like Bradshaw, also comments on the lack of social or political commentary in the film, and while I've argued that the film can be seen as symptomatic of Brexit Britain (Munro 2017) it, like all the films of this period, makes no attempt at significant commentary on Scottish and British constitutional relations in this period. T2: Trainspotting has little interest in whether it is still 'shite being Scottish'. Indeed, it is in a sense both more local and universal than it is national: Leith is by far a more 
omnipresent force in T2 than its predecessor Trainspotting, and as Murray (2017) has highlighted, an improbable scene in which Sick Boy and Renton pitch for EU development funds for their Leith-based brothel in the Scottish Parliament is a fleeting instance of the film's attempt to relate to a socio-political present. Beyond this, a sketch involving the robbery of cash from the members of a Protestant Orange Lodge is the film's only real attempt at national commentary, but again, like Filth, its use is limited to a knowing joke for local audiences: the lodge members all have the same PIN code - 1690 - a year of some notoriety for certain communities in Scotland. The four films above then perform Scottishness in various ways, though not always at an equal distance. I now turn to two films whose narratives relate specifically to Scottish-English national relations to analyse the national performativity of these two films, which I argue represent the extent to which Scottish cinema in this period has flagged national phenomena without aiming to provide any extended Political state-of-the-nation critique.

\section{White Settlers}

The film most clearly designed for topicality during the indyref period was the micro-budget horror film White Settlers, which depicts London yuppie couple Ed (Lee Williams) and Sarah's (Pollyanna McIntosh) move to the Scottish borders to take advantage of cheap house prices north of the border. Written by London-based Scot Ian Fenton, and directed by Englishman Simeon Halligan, the film attempts to use its generic horror narrative as political analogy. Director Halligan states: ' ...it's not a political film; primarily, it's a suspense thriller, it's more like a horror film. But the background to why it's going on has a political context' (Brown 2014). The political context being that the term 'White Settlers' is reference to a hard-line group of Scottish Nationalists in the early 1990s called Settler Watch, making the film's aim for political relevance 25 years out of date. But the film generated a little attention, though not much of a cinema release, due to its overt association with the independence referendum, even 
if the writer and director, while clear on their doubts about independence (ibid), tried to distance it from the debate - indeed claiming it struggled to secure a wide theatrical release because of the likelihood it would create controversy (Whittington 2014).

The film begins with the claim: 'The following is based on actual events'. Ironically filmed in Yorkshire, White Settlers depicts the terrorising of an incoming couple in the manner of Straw Dogs (1971) by the deceased previous owner's extended Scottish family, for reasons which are never quite made explicit, though it is implied relate to a feeling of their lands being colonised by incomers. The film's opening scenes flag the national overtly as Ed and Sarah try out Scottish accents on the drive north through the Borders, past a 'Scotland welcomes you sign' and a field of Highland cows, the latter being a recurring syntactic opening motif on Scottish cinema through Brigadoon (1954) to Dog Soldiers (2002). As Ed and Sarah are shown around the house the real estate agent tells them 'if you're not familiar with the lay of the land it's easy to run into trouble around here' (Halligan 2014). She also informs them the house sits on the site of a bloody battle between the Scottish and English. When asked who won, she remarks: 'it depends on who you talk to' (Halligan 2014). A cut to a few months later shows the couple unpacking their belongings and setting to work restoring the property. The film soon offers a first note of terror when Sarah gasps at finding a young boy with a Scotland football strip silently standing in their doorway. He quickly vanishes on his bike, riding away from the farmhouse to a threating musical score, revealing 'Tartan Army' on the back of his strip, right along the lines of Calder's (2002) argument that the imagery adopted by Scottish football fans was a deliberate attempt to distance themselves from their English counterparts who were associated with violent hooliganism in the 1980s.

One might read the derelict house, and its need of repair and modernisation, as symbolic of the political union between Scotland and England of 1707. In a time of economic ruin after the disastrous attempt at a Scottish colonial empire in modern day Panama, in which $25 \%$ of 
the country's capital was invested (Devine 2012a), Scotland's parliament voted to enter union with England. While the Scottish public were generally reluctant to enter this political union, its landed gentry were handsomely rewarded by the English for their cooperation, giving rise to Burns's [1792] (2003: 393) penultimate line to Such A Parcel of Rogues In A Nation, often used by Scottish nationalists: 'We're bought and sold for English gold'. In its representation of the dilapidated farmhouse which needs restored by a wealthy English couple, White Settlers seems to reinforce the mythology of Union, in which Scotland is to be salvaged and civilised by its imperial Southern neighbour in order to fulfil its potential.

As the evening progresses the couple are terrorised by a group of men wearing pig masks with Scottish accents. After a series of chases through the woods, and violent and gory interactions, the couple are rounded up by their pursuers. A fade to black is then followed by a montage re-introducing the interior of the farmhouse, before we get a long shot of the house from the outside, resplendent in sunshine as the newly re-instated Scottish family host a gathering in the garden. The Saltire, Scotland's national flag, hangs from a window, and the family are joined by the young boy in the Scotland football strip - this time with the pig mask on. The images are then slowed down and the threatening music intensifies as the young boy moves into close-up: the Scottish terror lives on. An epilogue shows Ed and Sarah being helped by passers-by to remove their gags and attend to their wounds in what appears to be Manchester. They have been unceremoniously sent home, very much not welcome in Scotland in contrast to the film's earlier inclusion of the Scottish tourist sign from the border.

As Martin-Jones (2009a) has shown, the horror genre has more recently in Scottish cinema represented the Scottish Highlands as the site of horror, finding terror in the idyllic wilderness. White Settlers follows a similar pattern, though its setting in the Scottish Borders somewhat alters the ability to read the film as representing the kind of culture clash that MartinJones (ibid) discusses between English visitors to their Highland destinations. The Scottish 
Borders, as Devine (2018) discusses, have not been looked upon with the same fetish for romantic mythology that the Highlands have, with their history as the final frontier for the British Empire, a land to be tamed and co-opted into the cause of British national identity. The use of the Borders may have created space for a more nuanced socio-political critique of relations between Scotland and England in this period, though this does not seem to have been the intent of the filmmakers. Indeed, director Halligan commented upon its release: 'For me, that element - the whole Scottish/English thing - was never any more than something that exists in a whole load of films and music, whether it's Braveheart or Culloden or Trainspotting' (Loxton 2014). The film is then slightly muddled in the way it both clearly aims to use ScottishEnglish relations in 2014 as a site of terror, but also tries to distance itself from that reading. On the one hand, the screenwriter argues that the film reflects unease in Scotland at wealthy English incomers buying homes up north and driving up house prices for locals ('the real story' the film claims to be telling). On the other hand, the director seems to believe that historical Scottish-English tensions are a fiction created by popular cultural texts like Braveheart and Trainspotting, though it's not clear how the battle of Culloden ${ }^{4}$ fits into this narrative. What does seem clear is that the film continues a trend, identified by Murray (2015: 147) in the Scottish cinema of the 2000s, which finds low-budget genre cinema eminently readable through traditional critical approaches which explore the national question in a Scottish context. More than this, it can also be related to Petrie's (2017) summation of the Scottish Gothic tradition, in which the Union of 1707 arguably created a ghostly Scottish Other, repressed by the Anglo-British self of prosperity and modernity. Craig (1996) argues that by being placed 'out of history' by rational British progress, Scotland had to resort to a caricatured and stereotyped trope of images to remain visible. As in Martin-Jones' (2009a) reading of Dog Soldiers, one might read White Settlers as a nationalist revenge fantasy where the repression of Scottish history (the displaced family) ruptures the sanctity of the modern-ideal British present 
(the English couple) to reassert Scottish national identity. In his analysis of the genre films of Neil Marshall, Murray (2013) contends that while Dog Soldiers may be slightly more complex, both Doomsday (2008) and Centurion (2010) re-assert the problematic narrative essentialism that to enter Scotland from the south is to venture into an antagonistic land outside of time which acts as either a salve or violent repudiation to the problems faced by civilised outsiders. Similarly, the conclusion drawn from White Settlers is that Scottish nationalists in the era of indyref cannot accommodate their English neighbours into their lands, and that this political moment has heralded a return of the long-repressed Scottish Other.

\section{Sunshine on Leith}

One such pop culture phenomenon interested in 'the whole Scottish/English thing' are The Proclaimers, whose long-held support for Scottish independence is often linked to their music. Cap in Hand, the second track from best-selling album Sunshine on Leith, is indeed overtly critical of their perception of a Scottish reliance on the English in the same way that McIlvanney's or Burns's poems were. The lyrics directly relate to arguments about Scotland's militaristic role in the creation of Empire, and their alleged subsequent subservience within the British imperial project:

We fight, when they ask us

We boast, then we cower

We beg

For a piece of

What's already ours

The Proclaimers (1989)

The Proclaimers, comprising twin brothers Charlie and Craig Reid, are vocal supporters of the SNP, and their songs frequently reference Scottish cultural, political and social contexts. Letter From America, which does feature in the 2013 film adaptation, is a 1987 song which 
links the Highland clearances to the Thatcherite decimation of Scotland's heavy industries. It juxtaposes the lands cleared in the name of economic progress by landlords in the early nineteenth century (Lochaber, Sutherland, Lewis and Skye) with the working-class communities made unemployed in the name of economic progress by the closure of plants and mines in their area (Bathgate, Linwood, Methil and Irvine). The Scottish Labour party made use of the song for political point scoring, when leader Johann Lamont riffed on the lyrics to exclaim 'Standard Life no more, RBS no more, Shipbuilding no more' (STV 2014) in reference to those companies and industries threatening job losses or relocation in the event of Scottish independence, an association which did not please The Proclaimers (Scotsman 2014).

Sunshine on Leith provides a relatively rare example of a clearly definable popular Scottish cinema, both in its financial success and ethnographic use of popular folk culture. The film was the $16^{\text {th }}$ most popular at the UK box office in 2013, and a third of the takings came from Scottish audiences, highlighting its uniquely popular appeal north of the border (BFI $2014)^{5}$. Adapted for the screen by the Scottish playwright of the musical, Stephen Greenhorn, and directed by Englishman Dexter Fletcher, Sunshine on Leith portrays Scottish soldiers, Davy (George Mackay) and Ally (Kevin Guthrie), returning home to Leith after a traumatic tour of Afghanistan. Greenhorn, a supporter of Scottish independence (National Collective 2013), choose the music of The Proclaimers as a way to structure a play around contemporary Scottish lives that would be '...not a Brigadoon or Rob Roy' (Smith 2018). Ally is in a relationship with Davy's sister Liz, (Freya Mavor) while Davy begins a relationship with Liz's English friend, Yvonne (Antonia Thomas). Liz turns down Ally's proposal for marriage, instead emigrating to America, while Davy and Yvonne's blossoming romance is temporarily derailed when Davy announces he wouldn't move to England with her. Davy's mother Jean (Jane Horrocks) and father Rab (Peter Mullan) similarly undergo relationship troubles when it is revealed Rab has a daughter, Eilidh (Sarah Vickers), he doesn't know about through a long- 
forgotten affair when she returns north from England for her mother's funeral. In what follows I investigate how the film provides what Murray calls 'an allegory of political indecision in devolution-era Scotland' (2019: 344).

From its opening scenes, Sunshine on Leith presents a complex and nuanced depiction of Scottish/British identities at the time of indyref, even if its diegesis makes no clear link to contemporary constitutional debates. That Davy and Ally are soldiers in the British Army is significant in highlighting of one of the primary ways in which Scottish identities were historically amalgamated into the cause of Britain. McCrone's survey of the ways in which 'Scotland became British' (2017: 15-16) offers three primary areas in which these identities were welded together: church, state and empire. In the cause of empire, Devine (2012b) and Colley (1992) both write of how one of the structuring forces of what Morton (1999, cited in McCrone 2017) calls a 'unionist-nationalism' was the use of Scottish soldiers as the face of British imperial expansion. Archibald (2008) is quite rightly sceptical of how the mythology around Highland battalions allows the country to negate its vigorous embracement of British imperialism. The reputation of the Scots, especially the Highlanders, as barbaric and fierce warriors was a predominant impression for the English attained through memories of centuries of bloody skirmishes, and one that the Scots' self-sufficiency in overseas mercenary endeavours further embellished. This pillar of unionism, then, the British Army, is ever-present in Sunshine on Leith. The maiming of their friend Ronnie (Paul Branigan) serves as implicit critique of the needless casualties caused by Britain's contemporary military aggressions. Ally's failure to win the heart of Liz, and his difficulty re-integrating into his home life - he stays with his sister, who is not particularly welcoming of him into her home ${ }^{6}-$ ultimately results in his decision to return to Afghanistan. One could read this as evidence that this militaristic Scottish-British identity has diminished relevance in contemporary Scotland. While the film is seen as an antidote to so-called Scottish miserabilism (Archibald 2013), it might be 
argued that its emptying of Scotland of the film's protagonists reiterates the clearances of The Proclaimers' Letter From America. Liz's decision to emigrate to America to further her career, the potential move of Davy and Yvonne to England and Ally's return to war, would seem to reinforce the sense that to leave Scotland is the primary means to self-fulfilment, as per Yule and Manderson's (2014) definition of Scottish miserablism. On the other hand, Rab and Jean vow to overcome Rab's infidelity to incorporate his English love-child into their lives. Supporting Murray's reading of this as political allegory, Jean asks Rab: 'Why do we stay together? Is it because we're too frightened to do anything else?' (Fletcher 2013). Rab insists that he must be a father to this newly-discovered daughter, but Jean is adamant that she can play no part in their lives if they are to remain a couple. At the end of the film, Jean has arranged for Eilidh to give them a lift home from the hospital after Rab's heart attack. This narrative strand, then, shows the healing potential for this broken family, of a union between cross-border generations.

Dyer argues that the musical is a genre often theorised as one which aims for utopia, in that it seeks to resolve societal tensions through escapism and wish-fulfilment to offer a vision of 'something better' (1981: 177). Feuer (1981) similarly writes that the musical aims to transcend the line between reality (narrative) and dream (musical numbers) in order to try and contain the ideological contradictions made implicit by their form and their socio-historical position to achieve a satisfactory resolution. Feuer (1981) notes that the musical's imperative is to present itself as natural and relatable to the audience's real lives, despite its inherently fantastical and technologically complex construction. In Dyer's (1981) analysis the musical tries to work through these contradictions through three common modes of address. The first firmly keeps narrative and numbers delineated, as in the case of the 'backstage' musical, where the numbers are clearly part of the realist construction of the narrative and the audience is integrated into this process of musical construction, as in A Star is Born (1954), or Singin' in 
the Rain (1952). The second category still retains the delineation between the problem of the narrative, and the escapism of the musical number, but attempts a degree of integration in that the musical numbers are cued up by the narrative. The third category of musicals are those which try hardest to dissolve the distinction between narrative and number, so that the musical numbers are inextricable from the progression of plot and character and, for Dyer '...suggest that utopia is implicit in the world of the narrative as well as in the world of numbers' (187). Or, in other words, the musical tries to disintegrate the dualism of 'dream' vs. 'reality', 'spoken' vs. 'song' (Feuer 1981) to present a unified, contained whole.

Sunshine in Leith is clearly a musical located within very specific and recognisable geographical and temporal spaces: that of Scotland in the $21^{\text {st }}$ century, although more local viewers may also be taken by the specificity of its depiction of Leith. I would argue that the film fits most neatly, though imperfectly, into Dyer's third category of musical, in which the songs arise from the narrative and are inseparable from it. Dexter Fletcher's design of the musical sequences would seem to correspond with this: 'It wasn't like, “Okay, the film's going along... stop! We'll have a song, and then we should be able to pick it up again." I wanted [the songs] to feel absolutely integral to what was going on' (Carty 2013). Adopting Dyer's approach, then, it might be argued that Sunshine on Leith is a musical representing a Utopian Union. The film's post-opening-credit opening shots of Edinburgh offer a highly fetishised tourist gaze aesthetic, with an aerial shot travelling from the Port of Leith into the city centre, taking in Edinburgh's famous castle. Though the film is undoubtedly readable as taking place in Edinburgh, and its dialogue and narrative concerns clearly relate to national phenomena, Sunshine on Leith also provides an example of what Martin-Jones (2009b) has called an increased regional visibility in the New Scottish Cinema. Though the keen viewer will notice Glaswegian streets and tenement stair wells at points, the film is at pains to remain rooted not only in Edinburgh, but particularly the Leith of its title. Davy's family live in a flat off Bernard 
Street, in Leith's Shore area, and are seen drinking in legendary pub The Port of Leith, where the song Let's Get Married plays out while the local punters watch an Edinburgh derby clad in the green and white of Edinburgh's great Hibernian football team. Rab and Jean's silver wedding anniversary party is held in Leith's well-kent Dockers club, as the film makes sure to make clear through an establishing shot. Earlier in the film, Charlie and Craig Reid stumble out of The Constitution, another Leith pub, with a knowing nod to Davy and Ally, and of course the audience, thus further cementing the regional specificity.

But in alliance with this, the film frequently flags the nation and its relationship with England. Sometimes this is played for comic effect. When Davy is told by Ally that his sister is setting him up with Yvonne, and that she's English, Davy stops dead in the street: 'She's English? English!?’ (Fletcher 2013). As aforementioned, this tension becomes apparent later in the film when Davy's family troubles prompt Yvonne to miss her own family in England. As they argue about whether Davy would follow Yvonne back home to England, the following dialogue shows the escalating tension:

Yvonne: 'Would you come with me?'

Davy: 'To England?'

Yvonne: 'Does it matter where?'

Davy: 'Well, aye, if it's England!'

By this point in the film, one might conclude that Davy had already made the ultimate sacrifice in moving from Leith to Yvonne's flat in the rather more salubrious surroundings of Corstorphine. Before their ultimate re-Union at the end of the film, Davy and Yvonne's relationship strains further highlights the film's articulate engagement with Scottish national identities. Yvonne laments the fact that she moved to Scotland for a man who could barely 
string a sentence together about their love but would cry like a baby at the sight of Glencoe ${ }^{7}$. This prompts Davy's performance of Misty Blue, featuring the lyric 'we tend to view this nation/through the condensation/ of a dirty glass'. It is clear, then, that the film evokes national phenomena repeatedly through its narrative, dialogue and a visual construction which both privileges local specificity, as well as a touristic visual fantasy of Edinburgh's historic grandeur.

The film's final scene manages to cleverly incorporate all of these elements into a performance of The Proclaimers' most famous song, 500 Miles. Through an oddly convoluted route, Yvonne walks to Waverley train station in Edinburgh's city centre to leave Davy, and Scotland, behind. Davy pursues and catches up with Yvonne, though not before parodying Renton's infamous engagement with the bonnet of a car in Trainspotting. Davy and Yvonne stand outside The National Gallery, above which fly a Union Jack and a Saltire, as Davy desperately tries to rescue their relationship. He assures her that she is part of his home and family now, and that he'd even move to England with her. This cues up the beginning of 500 Miles, with the pair joined by a communal flash mob of non-professional dancers made up of locals, tourists, school children, performance artists and police officers. In this sense, the film reiterates Feuer's (1981) argument that musicals often aim to incorporate the amateur and the professional in their numbers, to further acculture the non-professional audience to the world of the musical. Not only that, but the film's other central characters are also seen in their disparate locations singing along, furthering the sense of unity that culminates the film's narrative. As Davy and Yvonne kiss, with Edinburgh's famous skyline in the background, the camera floats away from the scene before ending on a freeze frame of the community, and one might read nation, in a joyous union of ramshackle utopian harmony. 


\section{Conclusion}

While those researching and thinking about Scottish cinema have made admirable progress in expanding its theoretical horizons beyond a limiting discussion of national identities, and the 'correct' way for Scottish cinema to explore those, this article has sought to question whether that might be to underestimate the extent to which the concept of nation remains important to many of the films being made in contemporary Scotland. It should be possible to investigate film's relationship to national themes and iconographies without assuming that cinema is constructive of national identity, or that it is the purpose of cinema to undertake an ideological autopsy of the state of Scottish-English/UK relations. Murray's (2019) recent summary of the past 20 years of Scottish film criticism, while typically erudite and comprehensive, affords little importance to the contemporary socio-political contexts of film production and consumption. I would argue that there is a danger that such an approach unmoors cinema as a cultural object from its historical and social contexts of creation. That is not to say, however, that film should be primarily read through such a historically-specifically national moment, or that it is the best way to do so, but in the case of the films analysed in detail above, as well as those which are briefly mentioned earlier in the chapter, there is a recurring tendency for Scottish cinema in the period of indyref to feature films which, to adapt Elsaesser's (2015) terminology, 'perform the national', in that they frequently utilise national symbols and are readable for their relation to socio-political contexts, without containing the type of address historically associated with a national cinema.

Of course, this is just one way in which these films can be understood. As Murray (2019) has highlighted, one of the key ways that Scottish cinema has been researched over the past 20 years is through a focus on the institutions and production processes which helped to create and sustain a flourishing film culture. White Settlers and Sunshine on Leith again show differing sides of this. Both are reliant to an extent on cross-border funding mechanisms, as 
well as cast and crew. While White Settlers was not given funding by Creative Scotland, and it is not clear whether the producers sought it, Sunshine on Leith received the maximum funding award possible at that time, $£ 300,000$. White Settlers is clearly primarily an English production, with the caveat of its Scottish screenwriter and lead actress Pollyanna McIntosh. Sunshine on Leith is a collaborative cross-border production on more equal footing, with a number of English cast members, its English director, its UK-wide source of funding through the BFI and backing from prestigious UK production company DNA Films, alongside the successful Glasgow-based Black Camel Pictures. While there isn't scope here to investigate further the industrial mechanisms through which both films were produced, it is apparent that Petrie's (2000) claim that Scottish cinema remains a devolved cinema, intertwined with UK-wide funding structures remains the case; and indeed Connor's (2016) analysis of Under the Skin, comes to a similar conclusion, albeit one which places this reliance of Scotland on England into the wider context of the UK's reliance on the US financing in the context of film production .

And it is on this point where I believe Elsaesser's theoretical refinement has worth, in that it allows for an analysis of films which are still engaged with representing and flagging national iconography, or are connected to national and transnational streams of funding and production processes, without necessarily burdening them with the task of national representation as a political goal. Certainly, White Settlers and Sunshine on Leith, do this, albeit in very different ways. White Settlers is clearly structured around the idea that there is crossborder tension between England and Scotland, which is resolved at the end of the film by the removal of the English protagonists by their Scottish hosts. Alternatively, Sunshine on Leith's narrative overcomes this tension and its protagonists choose to unify their cross-border families rather than see them broken up. 


\section{References}

Archibald, D. (2008), “'We're just big bullies...” Gregory Burke’s Black Watch', Drouth, 26, pp. 8-13.

Archibald, D. (2013), 'Why there's more to Scottish cinema than dour miserablism', Financial Times, 27 September. Available at <http://www.ft.com/cms/s/2/83076cac-251b11e3-9b22-00144feab7de.html> (accessed 11 August 2016).

Bakare, L. (2019), 'Try, try again: Cineworld bows to Robert the Bruce campaign', Guardian, 3 July. Available at < https://www.theguardian.com/film/2019/jul/03/try-tryagain-cineworld-bows-to-robert-the-bruce-campaign> (accessed 10 July 2019).

BBC (2016), 'Sunset Song voted Scotland's favourite book', BBC News, 17 October. Available at <http://www.bbc.co.uk/news/uk-scotland-37677187> (accessed 18 October 2016).

BBC (2018), 'New Scottish film studio announced', BBC News, 7 December. Available at <https://www.bbc.co.uk/news/uk-scotland-46465737> (accessed 30 May 2019).

Bergfelder, T. (2005), 'National, transnational or supranational cinema? Rethinking European film studies', Media, Culture \& Society. 27: 3, pp. 315-331.

BFI (2014), 'Statistical Yearbook 2014', BFI. Available at <http://www.bfi.org.uk/sites/bfi.org.uk/files/downloads/bfi-statistical-yearbook-2014.pdf> (accessed 21 October 2016).

BFI (2017), 'Statistical Yearbook 2017', BFI. Available at <https://www.bfi.org.uk/sites/bfi.org.uk/files/downloads/bfi-statistical-yearbook2018.pdf> (accessed 23 July 2019). 
Brown, S. (2011), ““Anywhere but Scotland?” Transnationalism and New Scottish Cinema', International Journal of Scottish Theatre and Screen, 4: 1. Available at <http://ijosts.ubiquitypress.com/articles/abstract/109/> (accessed 2 March 2020).

Brown, C. (2014), “'Scottish referendum horror” film coming soon', The Scotsman, 7 July. Available at < https://www.scotsman.com/arts-and-culture/film-and-tv/scottishreferendum-horror-film-coming-soon-1-3468125> (accessed 20 February 2019).

Burns, R. [1792] (2003), The Canongate Burns: The Complete Poems and Songs of Robert Burns, A. Noble and P.S. Hogg (eds), Edinburgh: Canongate.

Calder, A. (2002), Scotlands of the Mind, Edinburgh: Luath.

Carty, S. (2013), '500 Smiles: Dexter Fletcher on Sunshine on Leith', The Skinny, 30 September. Available at < https://www.theskinny.co.uk/festivals/edinburghfestivals/film/500-smiles-dexter-fletcher-on-sunshine-on-leith> (accessed 20 August 2019).

Colley, L. (1992), Britons: Forging the Nation, 1707-1837, London: Pimlico.

Collin, R. (2015), Twitter, 23 May. Available at <https://twitter.com/robbiereviews/status/602024394140086272> (accessed 3 June 2016).

Craig, C. (1996), Out of History: Narrative Paradigms in Scottish and British Culture, Edinburgh: Polygon.

Craig, C. (2014), 'The Case for Culture', Scottish Review of Books, 15 September. Available at < https://www.scottishreviewofbooks.org/2014/09/the-case-for-culture/> (accessed 4 February 2020).

Devine, T. (2012a), The Scottish Nation: A Modern History, London: Penguin. 
Devine, T. (2012b), To the Ends of the Earth: Scotland's Global Diaspora, 1750-2010, London: Penguin.

Devine, T. (2018), The Scottish Clearances: A History of the Dispossessed, 1600-1900, London: Allen Lane.

Dyer, R. (1981), 'Entertainment and Utopia', in R. Altman (ed.), Genre: The Musical, London: Routledge, pp.175-189.

Elsaesser, T. (2015), 'European Cinema into the Twenty-first century: Enlarging the Context?', in M. Harrod, M. Liz and A. Timoshkina (eds), The Europeanness of European Cinema: Identity, Meaning, Globalization, London: I.B.Tauris, pp. 17-32.

Feuer, J. (1981), 'The Self-reflective Musical and the Myth of Entertainment', in R. Altman (ed.), Genre: The Musical, London: Routledge, pp.208-215.

Gellner, E. (2006), Nations and Nationalism, Oxford: Blackwell, $2^{\text {nd }}$ edition.

Gibbon, L.G. (1932), Sunset Song, Edinburgh: Canongate Classics.

Hames, S. (2020), The Literary Politics of Scottish Devolution: Voice, Class, Nation, Edinburgh University Press.

Higson, A. (2000), 'The Limiting Imagination of National Cinema', in M. Hjort and S. Mackenzie, (eds), Cinema \& Nation, London: Routledge, pp.63-74.

Hjort, M. and Petrie, D. eds. (2007), The Cinema of Small Nations. Edinburgh University Press.

Lim, S.H. (2019), 'Concepts of transnational cinema revisited', Transnational Screens, 10: 1, pp. 1-12. 
Loxton, R. (2014), 'White Settler horror film writer cries foul over referendum "link", The Herald, 24 August. Available at < https://www.heraldscotland.com/news/13176480.whitesettler-horror-film-writer-cries-foul-over-referendum-link/> (accessed 20 July 2019).

Macpherson, R. (2015), 'The crisis in Scottish film is older than most people who work in it'. the producer's cut, March 12. Available at <https://robinmacpherson.wordpress.com/2015/03/12/the-crisis-in-scottish-film-is-olderthan-most-people-who-work-in-it/> (accessed 12 August 2016).

Marmysz, J. (2014), 'The Myth of Scotland as Nowhere in Particular', International Journal of Scottish Theatre and Screen, 7: 1, pp. 28-44.

Martin-Jones, D. (2009a), Scotland: Global Cinema: Genres, Modes and Identities, Edinburgh University Press.

Martin-Jones, D. (2009b), 'Scotland's other kingdoms: reconsidering regional and national identities in a growing small cinema', in J. Murray, F. Farley and R. Stoneman (eds), Scottish Cinema Now, Cambridge Scholars Press: Newcastle upon Tyne, pp. 105-121.

Massimi, F. (2019), 'Remapping Femininity: Johansson's Alien Transnationalism in Under the Skin', in J. Loreck, W. Monaghan and K. Stevens (eds), Screening Scarlet Johansson, London: Palgrave Macmillan, pp.145-163.

McArthur, C. ed. (1982), Scotch Reels: Scotland in Cinema and Television, London: BFI.

McCrone, D. (2001), Understanding Scotland: The Sociology of a Nation.,Oxon: Routledge, 2nd edition.

McCrone, D. (2009), 'National Identity and Culture in a Cold Climate: The Case of Scotland', Journal of Irish and Scottish Studies, 2: 2, pp. 53-66.

McCrone, D. (2017), The New Sociology of Scotland, London: Sage. 
Meir, C. (2015), Scottish Cinema: Texts and Contexts, Manchester University Press.

Munro, R. (2014), 'Irvine Welsh and the Adaptation Industry: Filth, a case study', International Journal of Scottish Theatre and Screen, 7: 2, pp.31-56.

Munro, R. (2017), 'T2: Trainspotting's obsession with the past says a lot about today', The Conversation, 30 January. Available at <https://theconversation.com/t2-trainspottingsobsession-with-the-past-says-a-lot-about-today-72117> (accessed 21 July 2019).

Munro, R. (2020), “"To see oursels as ithers see us”: textual, individual and national otherselves in Under the Skin', in R. Munro and M. Stewart (eds), Intercultural Screen Adaptation: British and Global Case Studies, Edinburgh University Press, pp.101-119.

Murray, J. (2012), 'Blurring Borders: Scottish Cinema in the Twenty-first century', Journal of British Cinema and Television, 9: 3, pp. 400-418.

Murray, J. (2013), 'Give a dog a bone: representations of Scotland in the popular genre cinema of Neil Marshall', Visual Studies, 28: 3, pp. 227-237.

Murray, J. (2015), The New Scottish Cinema, London: I.B.Tauris.

Murray, J. (2017), 'Film Reviews: T2: Trainspotting', Cineaste, Summer, vol. XLII, no. 2, pp.48-50.

Murray, J. (2019), 'Trainspotter's delight: Issues and themes in Scottish film criticism', in J. Hill (ed.), A Companion to British and Irish Cinema, London: Wiley-Blackwell, pp. 490509.

National Collective. (2013), 'Writer of Sunshine on Leith Is Voting Yes', National Collective, 18 October. Available at <http://www.nationalcollective.com/2013/10/18/writer-of-sunshine-on-leith-is-votingyes/> (accessed 20 August 2019). 
Nowland, B. and Finch, Z. (2014), Directory of World Cinema: Scotland, Bristol: Intellect Books.

Osborne, H. (2012), 'Sick Man of Europe Scotland has Highest Mortality Rate in 15-44 Age Group'. International Business Times, 20 November. Available at <http://www.ibtimes.co.uk/scotland-mortality-worst-europe-sick-young-workers-406767> (accessed June 28 2016).

Petrie, D. (2000), Screening Scotland, London: BFI.

Petrie, D. (2004), Contemporary Scottish Fictions, Edinburgh University Press.

Petrie, D. (2017), 'Scottish Gothic and the Moving Image: A Tale of Two Traditions', in C.M. Davidson and M. Germanà (eds), Scottish Gothic: An Edinburgh Companion. Edinburgh University Press, pp.181-194.

The Proclaimers (1989), 'Cap in Hand', Sunshine on Leith [CD], Oxford: Chipping Norton Recording Studios.

Scottish Parliament. (2012), Meeting of the Parliament, 15 November [online], Edinburgh. Available at $<$ http://www.parliament.scot/parliamentarybusiness/report.aspx?r=7965\&mode=html\#iob _72479> (accessed 12 February 2017).

Scotsman (2014), 'Scottish independence: Proclaimers anger at Lamont', Scotsman, 28 February. Available at < https://www.scotsman.com/news/politics/scottish-independenceproclaimers-anger-at-lamont-1-3323865> (accessed 20 July 2019).

Smith, G. (1919), Scottish Literature, Character and Influence, London: Macmillan. 
Smith, K. (2018), 'TAKING THE 'EASY' OPTION HAS BEEN SO REWARDING', Scottish Field, 5 April. Available at <https://www.scottishfield.co.uk/culture/taking-theeasy-option-has-been-rewarding-for-writer-stephen/> (accessed 20 August 2019).

STV (2014), 'Labour leader riffs on Proclaimers in independence jobs warning', STV, 27 February. Available at <https://stv.tv/news/politics/265664-johann-lamont-says-jobs-willleave-scotland-after-independence/> (accessed 20 July 2019).

Whittington, J. (2014), 'FrightFest: Interview With White Settlers Director Simeon Halligan’, Horror Channel, 23 August. Available at $<$ http://www.horrorchannel.co.uk/articles.php?feature=frightfest $\% 3 \mathrm{~A}+$ interview + with + wh ite+settlers+director+simeon+halligan\&category=frightfest $>$ (accessed 23 July 2019).

Whyte, C. (1998), ‘Masculinities in Contemporary Scottish Fiction', Forum for Modern Language Studies, 34: 2, pp. 274-85.

Yule, E. and Manderson, D. (2014), The glass half full: moving beyond Scottish miserabilism, Edinburgh: Luath.

\section{Filmography}

Arnold, A. (2006), Red Road. Verve Pictures.

Baird, J.S. (2013). Filth. Lionsgate UK.

Boyle, D. (1996). Trainspotting. PolyGram Filmed Entertainment.

Boyle, D. (2017), T2: Trainspotting. Sony Pictures Releasing.

Davies, T. (2015), Sunset Song. Metrodome.

Fletcher, D. (2013), Sunshine on Leith. Entertainment Film Distributors.

Glazer, J. (2013), Under the Skin. StudioCanal.

Gray, R. (2019), Robert the Bruce. Signature.

Halligan, S. (2014), White Settlers. Warwick Films.

Kurzel, J. (2015), Macbeth. StudioCanal.

Mackenzie, D. (2018), Outlaw King. Netflix. 
Mullan, P. (1998), Orphans. Downtown.

Peckinpah, S. (1971), Straw Dogs. Cinerama Releasing UK.

Ramsay, L. (1999), Ratcatcher. Pathé Distribution.

Ramsay, L. (2002), Morvern Callar. Universal Pictures UK.

\section{Notes}

${ }^{1}$ Note for example the long-heralded, and still awaited, arrival of a film studio in Scotland (BBC 2018), and MacPherson's (2015) discussion about the longevity of the debate.

${ }^{2}$ For further evidence of the extent to which national identity and constitutional politics remains prominent in Scottish public discourse, witness the tedious paranoia and parochialism which surrounded the cinema chain Cineworld's decision not to screen this film - later reversed - upon release (Bakare 2019).

${ }^{3}$ Playing on the historic label that the Scots are the 'sick man of Europe' (Osborne 2012).

${ }^{4}$ He may have been referring to Peter Watkins' influential and innovative docudrama Culloden (1964).

${ }^{5}$ Filth similarly had $32 \%$ of its box office takings from north of the border.

${ }^{6}$ How very Edinburgh: 'You'll have had your tea?'

${ }^{7}$ As well as being a site of great Highland beauty, Glencoe is infamous as the site of a Jacobite massacre in 1692, in which Clan MacDonald was murdered while they slept by government forces for their refusal to pledge allegiance to the new Protestant monarchs of Scotland, Ireland and England. 